\title{
Care Farming for People with Dementia; What Can Healthcare Leaders Learn from This Innovative Care Concept?
}

This article was published in the following Dove Press journal: Journal of Healthcare Leadership

\author{
Simone R de Bruin (D) ${ }^{1,2}$ \\ Ingeborg Pedersen ${ }^{3}$ \\ Siren Eriksen ${ }^{4}{ }^{4}$ \\ Jan Hassink ${ }^{5}$ \\ Lenneke Vaandrager (D) ${ }^{2}$ \\ Grete Grindal Patil (iD) ${ }^{3}$ \\ 'National Institute for Public Health and \\ the Environment, Bilthoven, the \\ Netherlands; ${ }^{2}$ Department of Social \\ Sciences, Wageningen University \& \\ Research, Health and Society, Wageningen, \\ the Netherlands; ${ }^{3}$ Faculty of Landscape and \\ Society, Department of Public Health \\ Science, Norwegian University of Life \\ Sciences, As, Norway; ${ }^{4}$ Faculty of Health \\ Sciences, Norwegian Advisory Unit on \\ Ageing and Health, Vestfold Hospital Trust, \\ Tønsberg, Norway; VID Specialized \\ University, Oslo, Norway; ${ }^{5}$ Wageningen \\ University \& Research, Wageningen Plant \\ Research, Agrosystems Research, \\ Wageningen, the Netherlands
}

\begin{abstract}
There is growing recognition that traditional dementia care models fall short for people with dementia and their family caregivers. This has led to a call for new dementia care approaches. In response to this call, innovations in long-term dementia care are taking place both in the community and in residential care. One of these innovations is the care concept called "care farming." Care farms are farms that combine agricultural activities with care and support services for a variety of client groups, including people with dementia. Although the concept is being implemented in an increasing number of countries, the Netherlands and Norway are still front-runners in providing and researching this innovative dementia care approach. Over the last couple of years, several research projects have been carried out in these countries addressing a wide range of issues related to dementia care provision at care farms and using a wide range of research methods. This paper synthesizes the knowledge that has been generated in these research projects. By sharing the knowledge obtained in the Netherlands and Norway, we hope to inspire leaders in healthcare undertaking similar efforts to innovate care for the increasing number of people with dementia. By providing starting-points for future research, we additionally hope to contribute to a research agenda to further advance the field.
\end{abstract}

Keywords: care farms, dementia care, green care, innovation, person-centered care

\section{Introduction}

There is growing recognition that traditional dementia care models fall short for people with dementia and their family caregivers. This has led to a call for new dementia care approaches no longer primarily focusing on the physical health of people with dementia but also on their psychosocial needs. ${ }^{1}$ Important elements of these psychosocial care approaches include a person-centered care environment in which the individual's needs are met, in which they are respected and in which there is attention for one's wellbeing, quality of life, dignity, and meaning in life. ${ }^{2,3}$

Acknowledging the importance of a different dementia care approach, innovation in dementia care is taking place both in community and residential care services. Several of these innovations include nature-based activities and services since these have been associated with improved health and wellbeing of people with dementia. ${ }^{3-9}$ Examples of nature-based activities and services for people with dementia include sensory gardens, horticultural therapy, the use of natural elements (eg, plants) in institutional settings, and local green spaces (eg, forests). Different interrelated pathways have been suggested by which nature is assumed
Correspondence: Simone R de Bruin Email simone.de.bruin@rivm.nl 
to positively affect health and wellbeing. Some pathways go through contact with nature (eg, viewing, walking). Other pathways go through spending time in a natural environment without consciously engaging with nature as such. ${ }^{10,11}$ For people with dementia, contact with nature and spending time in a natural environment have been associated with feelings of self-worth, a sense of autonomy, and identity, reduction of agitation and the incidence of falls, and improved mood, quality of life, and sleep. $^{6-9}$

In the Netherlands and Norway, the changed approach to dementia care has resulted in the implementation of an innovative nature-based care concept called "care farming." Care farms are farms that combine agricultural activities with care and support services for a variety of client groups, including people with mental health problems, troubled youth, and people with dementia. Care farms serving people with dementia either provide adult day services (ADSs) during weekdays, or $24 \mathrm{~h}$ nursing care as an alternative for nursing homes. Additionally, there is a small number of care farms providing evening or weekend services to people with dementia or respite services to family caregivers. ${ }^{12-14}$

Although the concept of care farming is gradually being implemented in other countries as well (eg, Germany, Austria, UK, Japan, South Korea, USA), ${ }^{15-18}$ the Netherlands and Norway are still front-runners in providing and researching this innovative dementia care approach (see Box 1 for some background information about the evolution of care farming in the Netherlands and Norway). Over the last couple of years, several research projects have been carried out in these countries addressing a wide range of issues related to dementia care provision at care farms and using a wide range of research methods. This paper synthesizes the knowledge that has been generated in these past and ongoing research projects for healthcare leaders, such as managers and health and social care professionals, to understand what dementia care provision at care farms entails and consider what can be learned from this innovative care concept for dementia care provision in their own settings. We will specifically focus on what the care environment at care farms looks like, the benefits of dementia care provision at care farms for people with dementia in terms of health and wellbeing, and the users of dementia care services of care farms. We additionally propose recommendations for healthcare leaders and future directions for science to further advance the field.
Box I Evolution of Care Farming in the Netherlands and Norway

The Netherlands

From the 1990s onwards, the agricultural sector has been increasingly involved in offering health and social care services to different client groups. Several societal changes have contributed to this development. Increasing pressure on the agricultural sector and changing demands from society changed the focus of farmers in the Netherlands. It generated an increasing interest in innovative diversification activities of farms such as recreation, food processing, home selling, and care farming. Additionally, in the health and social care sectors, there have been trends towards socialization and normalization of (long-term) care services. These trends required adaptations of existing care environments or innovative design of new ones. Care farms are an example of this. Finally, there has been a demand for reconnecting society and rural areas. Care farming has given new social roles to farms and farmers and contributes to inclusion of vulnerable groups and thereby fulfils the demand for social reconnection. ${ }^{19}$

The number of care farms in the Netherlands has increased rapidly, from 75 in 1998 to more than 1100 today. Important for the development of the care farm sector was the initiation of the National Support Centre Agriculture and Care in 1999. Its activities included supporting care farms, embedding agriculture and care in society and policy, developing a quality system, and facilitating exchange of information, experience, and knowledge. These activities increased the familiarity and acceptance of care farms by the health and social care sectors. Further, the funding structure of care services provided by care farms has been important for the expansion of the sector and its legitimacy. Before the 1990s pioneers found creative ways to obtain sufficient finances (eg labour integration funds, social assistance regulations, care innovation funds). From 1995 onwards, other types of funding systems became available for people using services of care farms such as national payment schemes for citizens in need of longterm care and personal care budgets. ${ }^{19}$

Initially, the main client groups of care farms were people with a learning disability and people with mental health problems. Care farms offered assisted workplaces to these client groups. It was gradually acknowledged that care farms could also be beneficial for other vulnerable client groups such as people with dementia. At the care farms, people with dementia could participate in adult day services programs which included involvement in different types of farm-related activities. The average numbers of clients and staff members and the income generated by care providing care services per farm increased in time. Regional organisations of care farms were established throughout the country and have developed into professional accredited organisations which give them access to long-term care budgets. ${ }^{20}$

Today, care farms are fully embedded in the health and social care systems and have developed sustainable funding structures. There is now a very diverse sector with care farms initiated by professionals with different types of backgrounds and competences (eg farmers, health or social care professionals, social entrepreneurs) providing services at different types of farms and providing services to a wide range of client groups. ${ }^{19}$

(Continued) 


\section{Box I (Continued).}

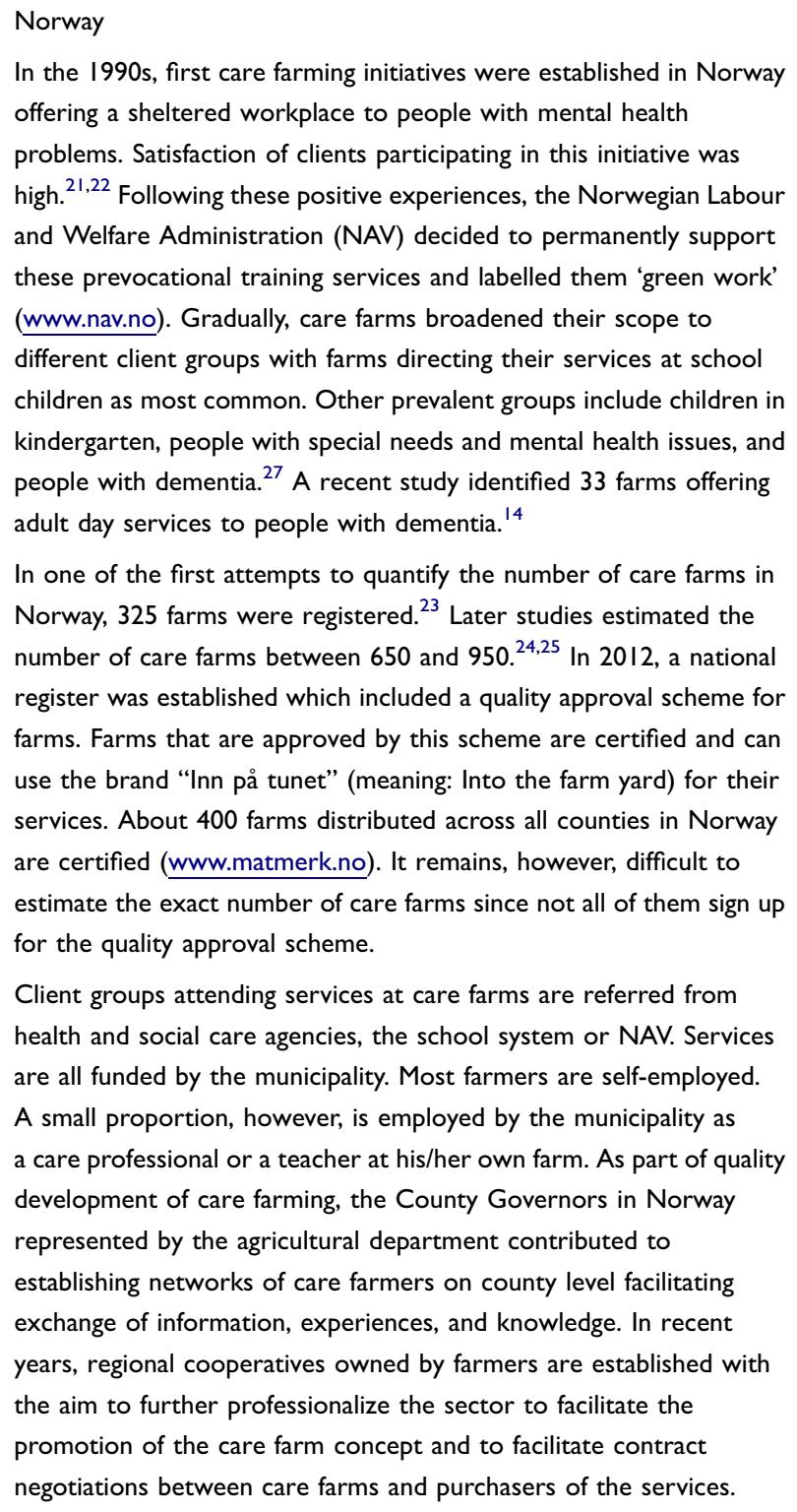

\section{What Does the Care Environment at Care Farms Look Like?}

Care farms generally have some degree of commercial farming (ie, crops, livestock, and woodland) combined with health, educational, and/or social services. There is great variation among care farms regarding the ratio between farming and these services, the types of farming activities (eg, dairy farm, industrial livestock farm, mixed farm),${ }^{14,26}$ and the client groups they serve. ${ }^{27,28}$ Many farmers and staff members have an education in agriculture, health, or social care (eg, registered nurses, nurse assistants, nurse aides, occupational therapists) and/or pedagogy. There are often volunteers assisting in the services. ${ }^{14,29,30}$ In the Netherlands, care farms offering services to people with dementia often collaborate with and/or hire staff of regular dementia care institutions, such as nursing homes.

Care farms have a wide range of health-promoting environmental characteristics, including the presence of outdoor spaces (eg, farmyard, vegetable garden, paddocks), farm and companion animals, plants, daily life stimuli, and a familiar and home-like environment. ${ }^{14,31-34}$ The different healthpromoting characteristics are naturally present in the farm environment and are therefore extensively used in the wide range of activities care farms offer to people with dementia. ${ }^{34-35}$ These activities, which are regarded as stimulating and meaningful, include walking outside, indoor horticulture activities, meal preparation, feeding and viewing the animals, picking eggs, gardening, sweeping the yard, crafts, woodworking, and playing games. ${ }^{14,33,34,36-38}$ Activity engagement and required physical effort to partake in activities at care farms are usually higher than in activities in regular dementia care environments. ${ }^{13,35,36,39}$ People with physical disabilities are able to participate in care farm activities as well. For them, activities are either adjusted or they are encouraged to participate in activities that require less physical effort.

Furthermore, the care farm environment ensures that the different activities are continuously present. This means that several activities stem from ordinary farm activities and do not necessarily need to be specially organized for people with dementia. Rather, they are tasks that need to be done as part of ordinary farm life. ${ }^{31}$ This is in contrast to regular dementia care environments where activities are often created for the purpose of inducing engagement and activity and are therefore only available at certain times. In regular dementia care environments, daily life is primarily organized around the routines of the institution and what is possible to carry out in an institutional setting. Activities, therefore, tend to be different from those offered by care farms, such as quizzes, listening to someone read aloud, music, crafts work, and chair exercise. ${ }^{31,35}$

To ensure that the care farm environment is used to its full potential, the roles of care farmers and other staff are extremely important. Factors such as the leadership of the farmer, the farmer's vision on dementia care, and competences of other staff (eg, creativity, flexibility, empathy, approach to care, innovative mindset), determine how the care environment and activities are included in dementia care provision. From different Dutch and Norwegian studies, we have learnt that farmers and other staff are very well able to organize 
meaningful activities, align these with personal needs, support a sense of mastery, and facilitate engagement of participants. This is in contrast to regular dementia care environments, where it has been observed that the institution may hinder engagement, for example, staff doing certain domestic activities (eg, meal preparation) themselves, without the involvement of people with dementia. ${ }^{29,31,33,38,40,41}$ Moreover, organizational aspects such as working routines in regular dementia care environments appear rigid and are often perceived as unalterable, which also complicates engaging people with dementia and using the physical environment in an optimal way. ${ }^{42}$

Potential downsides of an inviting and open environment, such as a care farm environment, are potential hazards. Activities such as cooking, caring for animals, and working with machinery can involve safety and health risks such as decreased hygiene, allergies, and the risk of stumbling. Care farms, having to conform to the same rules and regulations regarding risks and safety as regular dementia care environments, seem well able to manage these hazards. ${ }^{30,40}$ So far, no serious accidents have been reported.

\section{What are the Benefits of Dementia Care Provision at Farms in Terms of Health and Wellbeing?}

In several Dutch and Norwegian studies, the potential benefits of care farms for people with dementia in terms of health and wellbeing have been evaluated. These studies suggest that care farms support contact with nature and animals, time spent outdoors, activity engagement, physical activity, structure, social interactions, healthy eating, and a sense of meaning in life. As such, they differ from regular dementia care environments where lower levels of physical activity and activity engagement, less time spent outdoors, and fewer social interactions have been observed. ${ }^{35-36,38,39,42-45}$ Furthermore, participants and their family caregivers experience less stigmatizing because of dementia, since the care farm environment is a "normal" non-institutional kind of place. Instead, people with dementia may feel like a volunteer or employee rather than a patient with cognitive and functional impairments. People with dementia additionally feel recognized, understood, and seen as people who can deliver a meaningful contribution. The studies further reveal that care farms can also promote respite, more personal time, and fewer feelings of guilt among family caregivers. ${ }^{39,45,46}$
Based on these studies, it can be concluded that care farms have a wide range of benefits that might affect the health and wellbeing of people with dementia and their family caregivers.

\section{Who is Using Dementia Care Services of Care Farms?}

Care farms provide services to people with dementia in different stages of their disease. Generally, care farms offering adult day services serve people with mild to moderate dementia. Care farms providing $24 \mathrm{~h}$ nursing care also provide services to people that are in the later stages of the disease. In principle, people with dementia remain at the farm until death.

At present, care farms offering adult day services in the Netherlands seem to attract a distinctive client group in terms of demographic characteristics. People with dementia attending adult day services centers at a care farm are on average younger (about 71 years vs 85 years) and more often male than people with dementia attending adult day services centers affiliated to residential homes or nursing homes. ${ }^{36,42,46-48}$ Care farms do not intend to attract a distinctive client group. They are motivated to serve people with dementia of different sexes, ages, and backgrounds. In care farms providing $24 \mathrm{~h}$ nursing care in the Netherlands and in care farms offering adult day services in Norway, these differences are not visible or less pronounced.

People with dementia and their family carers who have chosen a care farm mentioned in studies by De Boer et $\mathrm{al}^{47}$ and De Bruin et $\mathrm{al}^{46}$ that the care environment at care farms and the services provided are more appealing to them and more in line with their preferences (eg, spending time outdoors, being physically active, gardening, taking care of animals) than regular dementia care environments and their services. This does, however, not imply that care farms are more attractive for those with an agricultural background, which is often thought. Several participants of care farms do not have any previous experience with country life or farms, and have occupational backgrounds in other sectors such as technology, education, or health care. ${ }^{14,33,46}$ Some family carers of clients of care farms indicated that if services at care farms had not been available, they would have postponed the use of adult day services or would have not used them at all as these would insufficiently meet the needs and capacities of their loved ones. ${ }^{38,46}$ 


\section{What Can Healthcare Leaders Learn from Dementia Care Provision at Care Farms?}

Building upon the knowledge generated by the different studies on care farming for people with dementia, we propose some recommendations for healthcare leaders to initiate dementia care innovation in their own contexts.

First, it is recommended that healthcare leaders willing to innovate dementia care provision consider how principles of dementia care delivery at care farms may be applied in their own contexts. Examples of these include a person-centered approach, addressing people's remaining capacities, incorporation of homelike and natural elements in the care environment, engagement of people with dementia in domestic activities, enablement of access to outdoor environments, and facilitation of contact with nature and animals. Several of these principles can also be applied in regular dementia care environments (eg, nursing homes, residential homes, adult day service centers). ${ }^{41}$

Second, in order to be able to implement principles of care farms, it is recommended that healthcare leaders create and contribute to an enabling environment which stimulates person-centered dementia care. Obviously, the physical environment in which a care institution is situated (eg, degree of urbanization, available space, presence of green elements, floor on which an adult day service center/ 24-h nursing care facility is located) will determine to a large extent how the environment can be used and what types of activities can be offered. However, an enabling environment is not only about its physical aspects; the social and organizational aspects are just as important. Examples of these include knowledge and willingness of management to innovate, management with an entrepreneurial attitude, and commitment at different organizational layers. Furthermore, the strong leadership of managers and appointed professionals will facilitate innovation. They could spread an innovative vision on dementia care provision and contribute to culture change. For instance, they could motivate and coach people in multiple organizational layers on how to evolve from purely medical care towards person-centered care, how to find a good balance between challenging clients and risk avoidance, how to make optimal use of the care environment, and how to align activities with one's capacities and wishes. Successful implementation of care farming principles also requires competent staff members; that is, staff being flexible and creative and having a progressive mindset that is open to change. ${ }^{30,33,40,49}$

Third, it is recommended that healthcare leaders seek innovative collaborations, particularly those who are unable to create innovative dementia care environments by themselves or in their own settings. In the Netherlands for instance, we see increasing numbers of dementia care institutions collaborating with social entrepreneurs. Dementia care institutions either initiate nature-based services together with these social entrepreneurs or use the green urban spaces managed by these social entrepreneurs (eg, community gardens, city farms, parks) for their clients with dementia. Such collaborations can be challenging, eg, because of cultural differences, differences in vision on dementia care provision, and different ideas about quality and safety issues, but are nevertheless considered as important. ${ }^{30}$

Fourth, it is recommended that healthcare leaders create opportunities for care professionals to further develop their competences. This may include facilitating the exchange of knowledge and experiences with care farmers to learn how principles of care farms are being applied or to learn how barriers for implementation of these principles have been solved. This also includes allowing training of current and future health and social care professionals about dementia care innovations. This might help to adopt a more psychosocial approach to care without ignoring the importance of high-quality medical and nursing care. ${ }^{40,50}$

\section{Which Questions Remain Unanswered?}

The Netherlands and Norway have been running services at care farms for several years now leading to an increasing body of evidence for the value of this kind of service for people with dementia (and other client groups), carers, and providers. Nevertheless, there are still several knowledge gaps that need to be addressed to further advance the field.

First of all, research on the long-term impact of attending adult day services or living at care farms is scarce. Most of the past and ongoing studies conducted so far either had qualitative approaches or had cross-sectional designs. We therefore recommend that the studies done so far are complemented by studies with longitudinal designs. As such, we will be able to answer research questions including: to what extent will physical activity at care farms slow down the deterioration of physical functioning? What is the impact of spending time outdoors on sleep patterns of people with 
dementia? How will living at a farm affect end of life processes? Will the temporary relief that care farms provide to family carers result in longer perseverance time or delay of institutionalization of the person with dementia? We therefore recommend that research and evaluation studies are supported so they can answer such questions.

A second area that might benefit from further research is how to align services at care farms more closely with the needs and capacities of people with dementia (and their carers) according to characteristics such as age, gender, and cultural background. The Dutch studies suggest that care farms provide services to relatively larger numbers of males, as compared to regular dementia care institutions. In the Netherlands, some care farms have started to offer activities that are more aligned with the preferences of females. It may be worthwhile to further explore why the participation of females is relatively low, and what will be necessary to attract more female clients.

Third, the potential value of providing care and support services to a combination of client groups (ie, not just people with dementia) at care farms is unknown. Some care farms have deliberately chosen to combine client groups since clients from different groups may support and stimulate each other. Other farms, however, have decided against this since client groups have different needs which, according to them, makes combining them undesirable. So far, research on care farming has focused on its benefits for specific client groups, eg, people with dementia, people with mental health problems, or troubled youth. ${ }^{39,41,43,51-53}$ It is therefore recommended that the potential value of combining client groups is explored in future research.

Fourth, there is a lack of knowledge on the impact of the presence of volunteers on the quality of dementia care provision. Most care farms, in addition to regular staff, involve substantial numbers of volunteers in the care provision. Their role is deemed important, particularly because as a result of their presence, people with dementia are supported to partake in activities that meet their needs, preferences, and capacities, as a wide range of activities can be offered simultaneously. Moreover, it has been suggested that volunteers contribute to the informal atmosphere at care farms. At the same time, however, it has also been suggested that volunteers, due to a lack of relevant education, may negatively affect quality of care. It would therefore be worthwhile to explore the role of volunteers in future research projects.

Fifth, so far, the Dutch and Norwegian studies primarily included respondents who had deliberately chosen a care farm. Knowledge about respondents who do not want to use the services of a care farm is lacking. It would be worthwhile to explore their views to be able to identify startingpoints to potentially improve the quality of these services.

\section{Overall Conclusion}

Although in the Netherlands and Norway a lot of experience has been obtained, in other countries care farming for people with dementia is still a new phenomenon in dementia care provision. The different studies suggest that dementia care at care farms is being appreciated by people with dementia and their family caregivers and might be beneficial for their health and wellbeing. By sharing the knowledge obtained in the Netherlands and Norway, we hope to inspire leaders in healthcare undertaking similar efforts to innovate care for the increasing number of people with dementia. Although much evidence is already available, much remains unknown. By providing starting-points for future research, we therefore additionally hope to contribute to a research agenda to further advance the field.

\section{Disclosure}

Ingeborg Pedersen and Grete Grindal Patil report grants from the Research Council of Norway, during the conduct of the study. The authors report no other conflicts of interest in this work.

\section{References}

1. Dröes R, Chattat R, Diaz A, et al. Social health and dementia: a European consensus on the operationalization of the concept and directions for research and practice. Aging Ment Health. 2016;21:1-14.

2. Cohen-Mansfield J, Dakheel-ali M, Marx MS, et al. Which unmet needs contribute to behavior problems in persons with advanced dementia? Psychiatry Res. 2015;228:59-64. doi:10.1016/j.psychres. 2015.03.043

3. Davis S, Byers S, Nay R, et al. Guiding design of dementia friendly environments in residential care settings: considering the living experiences. Dementia. 2009;8(2):185-203. doi:10.1177/147130120 9103250

4. Motealleh P, Moyle W, Jones C, et al. Creating a dementia-friendly environment through the use of outdoor natural landscape design intervention in long-term care facilities: a narrative review. Health Place. 2019;58:102148. doi:10.1016/j.healthplace.2019.102148

5. Hebert CA, Scales K. Dementia friendly initiatives: a state of the science review. Dementia. 2019;18(5):1858-1895. doi:10.1177/1471 301217731433

6. Cook M. Using urban woodlands and forests as places for improving the mental well-being of people with dementia. Leis Stud. 2019. doi:10.1080/02614367.2019.1595091

7. Gonzalez MT, Kirkevold M. Benefits of sensory garden and horticultural activities in dementia care: a modified scoping review. $J$ Clin Nurs. 2014;23(19-20):2698-2715. doi:10.1111/jocn.2014.23.issue-19 pt20 
8. Hendriks IH, van Vliet D, Gerritsen DL, et al. Nature and dementia: development of a person-centered approach. Int Psychogeriatr. 2016;28(09):1455-1470. doi:10.1017/S1041610216000612

9. Whear R, Coon JT, Bethel A, et al. What is the impact of using outdoor spaces such as gardens on the physical and mental well-being of those with dementia? A systematic review of quantitative and qualitative evidence. JAMDA. 2014;15(10):697-705. doi:10.1016/j. jamda.2014.05.013

10. Hartig T, Mitchell R, De Vries S, et al. Nature and Health. Annu Rev Public Health. 2014;35:207-228. doi:10.1146/annurev-publhealth -032013-182443

11. World Health Organization. Urban green space interventions and health: A review of impacts and effectiveness. Copenhagen: World Health Organization Europe; 2017.

12. De Boer B, Hamers JP, Beerens HC, et al. Living at the farm, innovative nursing home care for people with dementia - study protocol of an observational longitudinal study. BMC Geriatr. 2015;15:144. doi:10.1186/s12877-015-0141-x

13. De Bruin SR, Oosting SJ, van der Zijpp AJ, et al. The concept of green care farms for older people with dementia: an integrative framework. Dementia. 2010;9(1):79-128. doi:10.1177/1471301209354023

14. Ibsen TL, Eriksen S, Patil GG. Farm-based day care in Norway a complementary service for people with dementia. J Multidiscip Healthc. 2018;11:349-358. doi:10.2147/JMDH.S167135

15. Anderson KA, Chapin KP, Reimer Z, et al. On fertile ground: an initial evaluation of green care farms in the United States. Home Health Care Serv Q. 2017;36(1):1-15. doi:10.1080/01621424.2017. 1291390

16. Cho Y, Hassink J, Vaandrager L. Exploring the Development of Care Farming in South Korea. Korean J Agric Man Pol. 2019;46:420-443. doi:10.30805/KJAMP.2019.46.3.420

17. Yamazaki S, Ura C, Okamura T, et al. Long-term effects of rice-farming care on cognitive function and mental health of elderly people with cognitive impairment: a follow-up study. Psychogeriatrics. 2019. doi:10.1111/psyg.12409

18. Garcia-llorente M, Rubio-olivar R, Gutierrez-briceno I. Farming for Life Quality and Sustainability: a Literature Review of Green Care Research Trends in Europe. Int J Environ Res Public Health. 2018;15 (6):1282. doi:10.3390/ijerph15061282

19. Hassink J, Hulsink W, Grin J. Crossroad innovation in agriculture and health care: care farming as a multilevel and transsectoral phenomenon. NJAS. 2014;68(1):1-11.

20. Hassink J, Grin J, Hulsink W. Identity formation and strategy development in overlapping institutional fields. Different entry \& alignment strategies of regional organizations of care farms into the healthcare domain. JOCM. 2016;29(6):973-993. doi:10.1108/ JOCM-07-2015-0122

21. Lærum K, Lærum E, Sørbrøden Ø. Grønn omsorg $i$ Vestfold. Tilrettelagt sysselsetting for mennesker med psykiske lidelser. Drammen: Fylkesmannen i Vestfold; 2000.

22. Sørbrøden Ø, Lærum K. Grønn omsorg $i$ Vestfold. Tilrettelagt sysselsetting for mennesker med psykiske lidelser. Evaluering med vekt pa langsiktige virkninger for brukerne. Drammen: SND; 2003.

23. Fjeldavli E, Meistad T. Green Care - report of frequencies from a survey among Norwegian farmers. Centre for Rural Research, NTNU; 2004.

24. Logstein B, Bleksaune A. Trender i Norsk Landbruk. Hedmark (Vol. 8/10) (in Norwegian). Trondheim: Norsk senter for bygdeforskning; 2010 .

25. Stokke K, Paulsen Rye S. Inn på tunet. Nasjonal og regional organisering. Gårdbrukerens økonomi og erfaringer (in Norwegian). Oslo: Norsk institutt for landbruksøkonomisk forskning; 2007.

26. Hassink J, Hulsink W, Grin J. Care farms in the Netherlands: an underexplored example of multifunctional agriculture Towards an empirically grounded organization-theory based typology. Rural Sociol. 2012;77:569-600. doi:10.1111/j.1549-0831.2012.00089.x
27. Prestvik A, Nebell I, Pettersen I. Aktør-og markedsanalyse av Inn på tunet. RAPPORT 2013-4. Norsk institutt for landbruksøkonomisk forskning (NILF); 2013.

28. Hassink J, Zwartbol C, Agricola HJ, et al. Current status and potential of care farms in the Netherlands. NJAS. 2007;55(1):21-36.

29. De Boer B, Living at a green care farm: an innovative alternative for regular care in nursing homes for people with dementia [PhD thesis]. Maastricht: CAPHRI Care and Public Health Research Institute, department of Health Services Research, Maastricht University; 2017.

30. Hassink J, Vaandrager L, Buist Y, et al. Characteristics and challenges for the development of nature-based adult day services in urban areas for people with dementia and their family caregivers. Int J Environ Res Public Health. 2019;16(8):1337. doi:10.3390/ ijerph16081337

31. De Bruin SR, De Boer B, Beerens H, et al. Rethinking Dementia Care: the Value of Green Care Farming. JAMDA. 2017;18:200-203. doi:10.1016/j.jamda.2016.11.018

32. De Boer B, Beerens HC, Katterbach MA, et al. The Physical Environment of Nursing Homes for People with Dementia: traditional Nursing Homes, Small-Scale Living Facilities, and Green Care Farms. Healthcare. 2018;6(4):137. doi:10.3390/healthcare 6040137

33. Myren G, Enmarker I, Hellzen O, et al. The influence of place on everyday life: observations of persons with dementia in regular day care and at the green care farm. Health. 2017;9:261-278. doi:10.4236/health.2017.92018

34. Pedersen I, Patil G, Farm based day care services in Norway for people with dementia - expert identified key components, 14th International People Plant Symposium, IPPS2018; 2018; Sweden.

35. Ellingsen-Dalskau L, Pedersen I, De Boer B, Farm based day care services for people with dementia - an observational study. 29th Alzheimer Europe conference; 2019; The Hague.

36. De Bruin SR, Oosting SJ, Kuin Y, et al. Green care farms promote activity among elderly people with dementia. J Hous Elderly. 2009;23(4):368-389. doi:10.1080/02763890903327275

37. Myren G, Enmarker I, Hellzen O. Relatives' experiences of everyday life when receiving day care services for persons with dementia living at home — "It's good for her and its good for us". Health. 2013;5:1227-1235. doi:10.4236/health.2013.58166

38. Strandli EHA, Skovdahl K, Kirkevold Ø, et al. Inn på tunet- et helsefremmende tilbud-En studie om ektefellers opplevelse med dagaktivitetstilbud for personer med demens. Tidsskrift for omsorgsforskning. 2016;2(3):202-211. doi:10.18261/issn.2387-5984-2016-03-06

39. De Boer B, Hamers JP, Zwakhalen SM, et al. Green Care Farms as Innovative Nursing Homes, Promoting Activities and Social Interaction for People With Dementia. JAMDA. 2017;18(1):40-46. doi:10.1016/j.jamda.2016.10.013

40. Buist Y, Verbeek H, de Boer B, et al. Innovating dementia care; implementing characteristics of green care farms in other long-term care settings. Int Psychogeriatr. 2018;30(7):1057-1068. doi:10.1017/ S1041610217002848

41. Hassink J, Zweekhorst M, Elings M, et al. Care farms attractive empowerment-oriented and strengths-based practices in the community. Health Place. 2010;16:423-430. doi:10.1016/j. healthplace.2009.10.016

42. De Bruin SR, Buist Y, Hassink J, et al. "I want to make myself useful": the value of nature-based adult day services in urban areas for people with dementia and their family carers. Ageing Soc. 2019. doi: $10.1017 / \mathrm{S} 0144686 \mathrm{X} 19001168$

43. De Bruin SR, Oosting SJ, Tobi H, et al. Day care at green care farms: a novel way to stimulate dietary intake of community-dwelling older people with dementia? J Nutr Health Aging. 2010;14(5):352-357. doi:10.1007/s12603-010-0079-9

44. Finnanger Garshol B, Ellingsen-dalskau L, Pedersen I, Physical activity in day care services for people with dementia. 29th Alzheimer Europe conference; 2019; The Hague. 
45. Sudmann TT, Borsheim IT. It's good to be useful': activity provision on green care farms in Norway for people living with dementia. Int Pract Develop J. 2017. doi:10.19043/ipdj.7SP.008

46. De Bruin SR, Stoop A, Molema CCM, et al. Green care farms: an innovative type of adult day service to stimulate social participation of people with dementia. GGM. 2015;1:1-10.

47. De Boer B, Verbeek H, Zwakhalen SMG, et al. Experiences of family caregivers in green care farms and other nursing home environments for people with dementia: a qualitative study. BMC Geriatr. 2019;19 (1):149. doi:10.1186/s12877-019-1163-6

48. Ibsen I, Kirkevold Ø, Patil G, et al. People with dementia attending farmbased day care in Norway - Individual and farm characteristics associated with participants' quality of life. Health Soc Care Community. 2019. doi: $10.1111 /$ hsc. 12937

49. Hassink J, Grin J, Hulsink W. New practices of farm-based community-oriented social care services in the Netherlands. J Soc Serv Res. 2015;41(1):49-63. doi:10.1080/01488376.2014.937889
50. Backhaus R, Verbeek H, van Rossum E, et al. Future distinguishing competencies of baccalaureate-educated registered nurses in nursing homes. Geriatr Nurs. 2015;36(6):438-444. doi:10.1016/j.gerinurse.2015. 06.012

51. Pedersen I, Martinsen EW, Berget B, et al. Farm animal-assisted intervention for people with clinical depression: A randomized controlled trial. Anthrozoos. 2012;25(2):149-160. doi:10.2752/1753037 12X13316289505260

52. Pedersen I, Patil G, Berget B, et al. Mental health rehabilitation in a care farm context: A descriptive review of Norwegian intervention studies. Work. 2016;53(1):31-43. doi:10.3233/WOR-152213

53. Schreuder E, Rijnders M, Vaandrager L, et al. Exploring salutogenic mechanisms of an outdoor experiential learning programme on youth care farms in the Netherlands: untapped potential? Int J Adolesc Youth. 2014;19(2):139-152. doi:10.1080/02673843.2014.896267

\section{Publish your work in this journal}

The Journal of Healthcare Leadership is an international, peer-reviewed, open access journal focusing on leadership for the health profession. The journal is committed to the rapid publication of research focusing on but not limited to: Healthcare policy and law;Theoretical and practical aspects healthcare delivery; Interactions between healthcare and society and evidence-based practices; Interdisciplinary decision-making;
Philosophical and ethical issues; Hazard management; Research and opinion for health leadership; Leadership assessment. The manuscript management system is completely online and includes a very quick and fair peer-review system. Visit http://www.dovepress.com/ testimonials.php to read real quotes from published authors. 